JBL 123/3 (2004) 401-424

\title{
THE FORM AND FUNCTION OF THE SONG OF MOSES (DEUTERONOMY 32:1-43)
}

\author{
MATTHEW THIESSEN \\ bibliophilus@hotmail.com \\ Trinity Western University, Langley, BC, V2Y 1Y1, Canada
}

G. Ernest Wright has argued in "The Lawsuit of God: A Form-Critical Study of Deuteronomy 32" that the genre of the Song of Moses is that of a "covenant lawsuit" or rîb. ${ }^{1}$ This argument has been highly influential in subsequent research on the Song and is almost taken for granted by many now. ${ }^{2}$ But not all have followed Wright's analysis. A number of criticisms have been leveled, and it has instead been argued that the Song belongs to the sphere of wisdom literature. ${ }^{3}$ In this article, I will examine Wright's analysis of the Song, which I find wanting in regard to a number of features in the Song. I will show that the designation "covenant lawsuit" is only a partial description of the form and function of the Song, and I will argue that the Song evinces qualities of a number of different forms but that it broadly fits the category of a hymn. After demonstrating the hymnic elements that are found in the Song, I will conclude with some comments regarding the implications of these findings for the study of the Song.

${ }^{1}$ G. Ernest Wright, "The Lawsuit of God: A Form-Critical Study of Deuteronomy 32," in Israel's Prophetic Heritage: Essays in Honor of James Muilenburg (ed. Bernhard W. Anderson and Walter Harrelson; New York: Harper \& Brothers, 1962), 26-67.

${ }^{2}$ See, e.g., J. A. Thompson, Deuteronomy: An Introduction and Commentary (TOTC 5; Leicester: InterVarsity Press, 1974), 296-97; A. D. H. Mayes, Deuteronomy (NCB; Greenwood, SC: Attic Press, 1979), 380-81; Patrick D. Miller, Deuteronomy (Interpretation; Louisville: John Knox, 1990), 226; Ian Cairns, Word and Presence: A Commentary on the Book of Deuteronomy (ITC; Grand Rapids: Eerdmans, 1992), 278-90; Christopher Wright, Deuteronomy (NIBC 4; Peabody, MA: Hendrickson, 1996), 297-98.

${ }^{3}$ Particularly, James R. Boston, "The Wisdom Influence upon the Song of Moses," JBL 87 (1968): 198-202.

401

This article was published in JBL 123/3 (2004) 401-424, copyright ( 2004 by the Society of Biblical Literature. To purchase copies of this issue or to subscribe to JBL, please contact SBL Customer Service by phone at 877-725-3334

[toll-free in North America] or 802-864-6185, by fax at 802-864-7626, or visit the online SBL Store at www.sbl-site.org. 


\section{G. Ernest Wright’s Analysis}

Wright first provides a structural analysis of the Song, dividing it into seven sections, acknowledging that his divisions are based on attempts "to identify thought units." 4 These sections are as follows:

Section 1 Introduction (Deut 32:1-6)

Section 2 Kerygma: Appeal to mighty acts of God (vv. 7-14)

Section 3 Indictment (vv. 15-18)

Section 4 Sentence or penalty (vv. 19-29)

Section 5 Poet's assurance of salvation (vv. 30-38)

Section 6 The Word of YHWH confirming poet's hope (vv. 39-42)

Section 7 Poet's final exhortation to praise (v. 43)

Based on this structure, Wright concludes that "basic to the Song is one distinguishable form which the psalmist has elaborated. This is the divine lawsuit, or rîb." He argues that this pattern is central to Deut 32:1-43 as shown by three things: the summons to witnesses in v. 1, the indictment in vv. 15-18, and the judge's verdict in wv. 19-29. ${ }^{6}$ Wright then compares the Song to Herbert B. Huffmon's outline of the form of the covenant rîb, which is provided below.

I. Description of the scene of judgment

II. Speech of plaintiff

A. Heaven and earth appointed judges

B. Summons to defendant (or judges)

C. Address in second person to the defendant

1. Accusation in question form to defendant

2. Refutation of defendant's possible arguments

3. Specific indictment ${ }^{7}$

Wright makes two modifications of the analysis provided by Huffmon. First, he does not believe that heaven and earth function as judges in the law-

${ }^{4}$ Wright, "Lawsuit," 34-36.

${ }^{5}$ Ibid, 42.

${ }^{6}$ Ibid, 43. For a description of this form, see Hermann Gunkel and Joachim Begrich, Introduction to the Psalms: The Genres of the Religious Lyric of Israel (trans. James D. Nogalski; Macon, GA: Mercer University Press, 1998), 279-80. This form category itself is not uncontested. Two articles have been published providing critique of this genre. Michael De Roche criticizes the term and concept of a "covenant lawsuit" as an appropriate translation for ("Yahweh's Rîb Against Israel: A Reassessment of the So-Called 'Prophetic Lawsuit' in the Preexilic Prophets," JBL 102 [1983]: 563-74). For a more thorough critique of the whole genre of the rîb, see Dwight $R$. Daniels, "Is There a 'Prophetic Lawsuit' Genre?" ZAW 99 (1986): 339-60. Both of these criticisms fall short in that they assume that no modification could take place within the form.

${ }^{7}$ Herbert B. Huffmon, "The Covenant Lawsuit in the Prophets," JBL 78 (1959): 285-95, here 285. Huffmon bases his description on the work of Gunkel, Introduction, 279-80.

This article was published in JBL 123/3 (2004) 401-424, copyright @ 2004 by the Society of Biblical Literature. To purchase copies of this issue or to subscribe to JBL, please contact SBL Customer Service by phone at 877-725-3334 [toll-free in North America] or 802-864-6185, by fax at 802-864-7626, or visit the online SBL Store at www.sbl-site.org. 
suit; rather, they are witnesses to it. ${ }^{8}$ Second, he adds to this outline one more section, in which God, or a prophet as his spokesperson, declares the sentence. Fitting the Song of Moses into this outline, we have the following:

\begin{tabular}{|c|c|c|}
\hline & Outline of Lawsuit & Song of Moses \\
\hline I. & Description of the Scene of Judgment & --- \\
\hline & Speech of Plaintiff & $\mathrm{vv}, 1-29$ \\
\hline & A. Heaven and Earth Appointed Witnesses & v. 1 \\
\hline & B. Summons to Defendant & --- \\
\hline & C. Address in Second Person to the Defendant & vv. 4-29 \\
\hline & 1. Accusation in Question Form to Defendant & vv. $4-6$ \\
\hline & 2. Refutation of Defendant's Possible Arguments & vv. $7-14$ \\
\hline & 3. Specific Indictment & vv. $15-18$ \\
\hline & 4. Declaration of Sentence & vv. 19-29 \\
\hline
\end{tabular}

Most discussions of Wright's argument end at this point-which is unfortunate, since they miss one of the key steps in his argument: that within the Song of Moses there are a number of expansions to the form of the covenant $r i ̂ b$. These two expansions are found in v. 2 and in vv. 30-43. The first expansion is the wish of the poet in v. 2: "May my teaching fall as the rain; May my word distill as the dew, as rain upon grass, and as showers upon vegetation." Wright believes that by v. 2 the poet hints that the lawsuit form he uses is only an "instructional device." " This will be discussed further below.

The second, lengthier expansion is the last thirteen verses of the Song. Wright views this as a hymnic section meant to convey forgiveness to the people after the lawsuit has been declared. These two expansions demonstrate to Wright that, although the lawsuit form is the primary form of the Song, it is being used only as a didactic instrument through which the people confess their sin and receive absolution.

\section{Critique of Wright's Analysis}

One argument in particular of Wright's work has received criticism and should be reexamined here. He offers three reasons why he believes the Song is

${ }^{8}$ Huffmon ("Covenant Lawsuit," 286) does not provide argumentation for seeing a judiciary role attributed to heaven and earth; he merely agrees with Gunkel's analysis. But Gunkel himself does not appear to argue this. He does state, somewhat ambiguously, that "heaven and earth are brought to judgment" (Introduction, 279), but then states that YHWH acts as judge (p. 280).

${ }^{9}$ Wright, "Lawsuit," 54.

This article was published in JBL 123/3 (2004) 401-424, copyright @ 2004 by the Society of Biblical Literature. To purchase copies of this issue or to subscribe to JBL, please contact SBL Customer Service by phone at 877-725-3334 [toll-free in North America] or 802-864-6185, by fax at 802-864-7626, or visit the online SBL Store at www.sbl-site.org. 
a lawsuit: summons of witnesses in v. 1; indictment section in vv. 15-18; verdict of judge in vv. 19-29. It is in regard to the first point that Wright has come under fire. This is so because nothing in the Song itself states that heaven and earth are meant to function as witnesses to a rîb between YHWH and his people. That this is how the editor of the book of Deuteronomy understood their function is clear both from the narrative leading up to the giving of the Song (Deut 31:28) and from the function of heaven and earth in Deuteronomy as a whole (cf. 4:26; 30:19). But to equate the understanding of the editor of Deuteronomy with the understanding of the author of the Song of Moses is tendentious. Wright knows this and thus appeals to other examples where heaven and earth are called on in Jewish Scriptures—-these instances are Isa 1:2; Mic 6:2; Jer 2:4-14; and Ps 50 — all of which Wright believes are examples of the divine lawsuit. The first and the last are the only two that refer to both the heaven and the earth. In Mic 6:2, the prophet calls to the mountains and foundations of the earth. In Jer 2:12, YHWH calls only to the heavens, and it is not a summons to hear, but a command for them to be appalled.

James R. Boston has challenged Wright's arguments about this summons. ${ }^{10} \mathrm{He}$, too, believes that the three passages in Deuteronomy (4:26; 30:19; $31: 28)$ are from a later editor and are therefore relatively unimportant in understanding how heaven and earth function in the Song itself. He notes that Wright does not examine every invocation of the heavens and earth that appears in the Hebrew Bible. ${ }^{11}$ Boston believes that Wright has skewed the data by comparing Deut 32:1 only to these passages and to the other three passages in Deuteronomy. It might appear that Wright assumes the very thing he is attempting to prove in his comparison with the other four passages. He is attempting to demonstrate that the heavens and earth in Deut 32:1 function as witnesses, and this is an attempt to show that the Song of Moses is a lawsuit. But he compares the passage only to other passages that he believes are lawsuits, thus predetermining his conclusion. Instead, Boston argues, all passages that address the heavens and the earth (together or individually) need to be examined to determine what their function is. Only then can their role in Deut 32:1 be examined. Since Wright includes Mic 6:2, which refers not to heaven or earth but to the mountains, references to mountains ought to be included as well. But reexamining the data actually confirms Wright's conclusion. Of the numerous summons to heaven, earth, and mountains in Scripture, the majority fall into two distinct groups: (1) texts in which heaven, earth, or mountains are invoked in a context of judgment; (2) texts in which the natural phenomena occur in the context of a redemptive message.

10 Boston, "Wisdom Influence," 198-202.

11 Boston himself attempts to do this but only discusses eleven such instances ("Wisdom Influence," 198-99).

This article was published in JBL 123/3 (2004) 401-424, copyright @ 2004 by the Society of Biblical Literature. To purchase copies of this issue or to subscribe to JBL, please contact SBL Customer Service by phone at 877-725-3334 [toll-free in North America] or 802-864-6185, by fax at 802-864-7626, or visit the online SBL Store at www.sbl-site.org. 
In the first group there are six instances outside of Deut 32:1, all in the prophets. ${ }^{12}$ The data can be summarized in a chart:

\begin{tabular}{|c|c|c|}
\hline Passage & Addressee & Commands \\
\hline Isa $1: 2$ & heaven and earth & אזן, שמע \\
\hline Jer 2:12 & earth & חרב ,שער ,שמם \\
\hline Jer 6:19 & earth & שמע \\
\hline Ezek $6: 1,3$ & mountains of Israel & שמע \\
\hline Mic 1:2 & earth & קשב \\
\hline Mic 6:2 & mountains & שמע \\
\hline
\end{tabular}

What is apparent from these data is that generally when heaven, earth, or mountains are invoked in a context where a message of judgment is delivered, the verbal command has to do with hearing and is usually the verb שמע. The only time a verb of hearing is not present is in Jer 2:12, where the earth is commanded to be appalled-but even this implies hearing. The earth is to be appalled once it has heard the charge leveled at YHWH's people.

There are six texts in the second group, in which the natural phenomena are summoned in the context of a redemptive message.

\begin{tabular}{|c|c|c|}
\hline Passage & Addressee & Commands \\
\hline Isa $44: 23$ & heaven, earth, mountains & פצח, ריע ,רנן \\
\hline Isa 49:13 & heaven, earth, mountains & רנה,גיל ,רנן \\
\hline Ezek 36:1, 4 & mountains & שמע \\
\hline $\begin{array}{l}\text { Ps } 69: 35 \text { (v. } 34 \\
\text { in Engish) }\end{array}$ & heaven and earth & 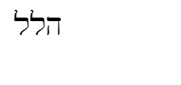 \\
\hline Ps $96: 11^{*}$ & heaven and earth & גיל ,שמח \\
\hline Ps $148: 4$ & heaven & 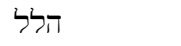 \\
\hline
\end{tabular}

As would seem most fitting, songs that summon heaven, earth, or mountains in the context of YHWH's creative and redemptive work primarily summon them to rejoice and celebrate that work. ${ }^{13}$

${ }^{12}$ Jeremiah 22:29 also contains a command to the land (שרמע) to hear (שרץ), but here "land" refers to the people of the land. Here too the context is one of judgment.

${ }^{13}$ Many psalms could be added to this category. Multiple times in the Psalter, the "earth" is

This article was published in JBL 123/3 (2004) 401-424, copyright @ 2004 by the Society of Biblical Literature. To purchase copies of this issue or to subscribe to JBL, please contact SBL Customer Service by phone at 877-725-3334 [toll-free in North America] or 802-864-6185, by fax at 802-864-7626, or visit the online SBL Store at www.sbl-site.org. 
Finally, there are a number of anomalous passages. Isaiah 45:8 calls on the heavens and the earth themselves to provide salvific blessing to the people, as does Ps 72:3. Lastly, in two psalms, 33:8 and 114:7, the earth is commanded to tremble at the presence of YHWH. This survey shows that heaven, earth, and mountains serve a number of different functions when imperatives are addressed to them. ${ }^{14}$ In this much Boston is right, but he does not go far enough. What he fails to note is that the context in which these elements are commanded in some way dictates the imperatives used in summoning them. As the charts show quite clearly, in all but one instance of the invocation of these elements in the context of a judgment oracle, they are called to hear. And in the context of redemption, except for one instance, the commands are to rejoice. The exception is Ezek 36:1, 4 in which the mountains are called to hear (שמע). This anomaly of the mountains being called to hear in the context of redemption is likely explained by the fact that previously, in Ezek 6:1-3, YHWH had commanded the prophet to speak a judgment oracle to the mountains of Israel calling them to hear. Thus, the command to hear in Ezek 36 has to do with bringing about a certain degree of symmetry with Ezek 6 . The earlier oracle of judgment in Ezekiel governs the verb used in Ezek 36, despite the invocation taking place within the context of redemption. When Boston argues that on "the basis of this evidence of variety of function, it would seem that one should not attempt to put very much emphasis on the use of the expression as an element in any specific literary form," 15 he is right, insofar as he means a general invoking of the heavens or earth. But the combination of the invocation of these elements with the command to hear is clearly seen to belong primarily to a judgment context, to which the rîb pattern belongs. Since Deut 32 begins with the phrase "Give ear, O heavens, and I will speak, and let the earth hear the words of my mouth," it is most naturally associated with the rîb. This, coupled with Wright's other two points (indictment section in vv. 15-18; verdict of judge in vv. 19-29), demonstrates that the covenant lawsuit is indeed found in Deut 32.

While Wright's theory has much to commend it, a number of problems do arise from his work that must be dealt with before another overarching form designation can be suggested. One of the first and most basic criticisms is of Wright's method of determining the structure of the Song based on "an attempt to identify thought units."16 This method leaves the interpreter open to being

paralleled to "inhabitants of the world" and called to praise. Such a meaning for earth cannot be excluded outright from these other passages.

${ }^{14}$ Perhaps it is somewhat arbitrary to examine summons only to heaven, earth, and mountains. Other aspects of creation are also summoned in Scripture; see Pss 96:11-12 and 148:3, where the sea, field, forest, sun, moon, and stars are also invoked in the context of praise.

${ }^{15}$ Boston, "Wisdom Influence," 199.

${ }^{16}$ Wright, "Lawsuit," 34.

This article was published in JBL 123/3 (2004) 401-424, copyright @ 2004 by the Society of Biblical Literature. To purchase copies of this issue or to subscribe to JBL, please contact SBL Customer Service by phone at 877-725-3334 [toll-free in North America] or 802-864-6185, by fax at 802-864-7626, or visit the online SBL Store at www.sbl-site.org. 
swayed by her or his own preconceptions of the form and meaning of a passage instead of possibly challenging those preconceptions. Wright admits this but does not attempt a more disciplined approach, ${ }^{17}$ which would deal with aspects that are more fundamental to the Song, such as grammar and speaker, from which a different understanding of the Song might present itself.

Wright realizes that his argument encounters a number of difficulties with the content of the Song-as noted above, v. 2 and vv. 30-43. He believes these are expansions of the lawsuit form that adapt it to use as a confession and absolution of the people's sin. But this could possibly lead to relegating these portions of the Song to a position of subordinate status. ${ }^{18}$ These latter two weaknesses with Wright's thesis justify a reexamination of the form of the Song that pays close attention to its key grammatical features and will attempt to do justice to the covenant lawsuit as well as to aspects that do not fit that form. It is my argument that understanding the Song as a hymn with an embedded rîb does the most justice to the content and structure of the Song. Before proposing that the Song belongs to a specific form, I will first show that it belongs within a particular sphere- that of the cult. This will involve examining grammatical features of the Song, which will lead to a structural analysis of the Song different from that presented by Wright. Once this has been established, we will be in a better position to address the issue of its form.

\section{The Liturgical Origin of the Song of Moses}

It is my contention in this article that various features of the Song of Moses are otherwise inexplicable unless it is understood to have originated in the context of liturgical worship. ${ }^{19}$ Even the fact that Deut 32:1-43 is called

\footnotetext{
${ }^{17}$ Ibid, 33.

${ }^{18}$ So too Huffmon, who argues that vv. 26-43 "may be an appendix stating why Yahweh will remit the sentence" "Covenant Lawsuit," 289).

19 The word "liturgical" is here being used in the rather broad sense of words that accompany a public cultic ceremony. Sigmund Mowinckel's definition of "cult"/"ritual" is apt: "The cult is, as mentioned above, the visible and audible expression of the relation between the congregation and the deity” (The Psalms in Israel's Worship [trans. D. R. Ap-Thomas; 2 vols.; New York: Abingdon, 1967], 16). These words, according to Mowinckel, "seem originally to belong to the acts as interpretation and complement- - that also being one side of the cult's dramatic character" (ibid., 20). Such words were by nature fixed rather than spontaneous. But see Erhard S. Gerstenberger, who suggests that cult should not be confined merely to a centralized place of worship but in early Israel should be thought to be a part of clan and tribal life (Psalms: Part I with an Introduction to Cultic Poetry [FOTL 14; Grand Rapids: Eerdmans, 1988], 5-9, 21-22).

Others have argued that the Song is in fact liturgical, but they have not demonstrated to my satisfaction the evidence that leads to this conclusion or the implications of this conclusion. See
}

This article was published in JBL 123/3 (2004) 401-424, copyright ( 2004 by the Society of Biblical Literature. To purchase copies of this issue or to subscribe to JBL, please contact SBL Customer Service by phone at 877-725-3334 [toll-free in North America] or 802-864-6185, by fax at 802-864-7626, or visit the online SBL Store at www.sbl-site.org. 
("The Song") points to some liturgical use of the passage. But this is not the only evidence of the liturgical use of the Song. Perhaps the most blatant anomaly is the number of changes of person that take place throughout the Song. Within a short space Israel is referred to in a number of different grammatical persons; these shifts need some explanation to account for them. In v. 5, for instance, the people of Israel are mentioned in the third person plural ("they"), but in v. 6, Israel is addressed in the second person singular ("you"). This continues into v. 7; the following verses, however, revert back to the third person until v. 14d. In v. 14d the people are again directly addressed in the second person: "and the blood of fine wine you drank." Again, such a shift takes place in v. 15, this time within the space of a single verse. In the first stichs of v. 15, Israel is referred to in the third person ("Jacob"/"Jeshurun"/"he"); however, in the next three verbs Israel is addressed in the second person singular ("you"). ${ }^{20}$ Just as quickly, the subject of the last two verbs reverts back to referring to Israel in the third person. Two verses later this happens again. "They sacrificed to demons" (v. 17a), to gods "whom your fathers did not fear" (v. 17d). The second person continues for the entirety of $\mathrm{v}$. 18 before giving way to the speech of YHWH in vv. 19-27. After YHWH's speech, the nation is again referred to in the third person ("they"). But in v. 31 "Israel" speaks in the first person plural: "For their rock is not as our Rock, even our enemies themselves being judges." ${ }^{21}$ In YHWH's third speech (Deut 32:37-42), the shift again is from the third person (v. 37) to the second person (v. 38). ${ }^{22}$

Within the span of forty-three verses, Israel is referred to in the third person, is directly addressed in the second person, and refers to itself in the first person; and these three ways of referring to the nation are woven together throughout the Song. The explanation for the shifts may be found in the cultic practices of Israel. These shifts in person with reference to Israel indicate that

Umberto Cassuto, who states that the Song "[i]s to be regarded as a liturgical composition for the New Year's festival, dating from the age of the Judges" (Biblical and Oriental Studies [trans. Israel Abrahams; 2 vols.; Jerusalem: Magnes Press, 1973], 1:46).

${ }^{20}$ The LXX apparently misses the significance of this shift in person, making the subject of all the verbs in the verse third person singular.

${ }^{21}$ The antecedent of "their" in this verse is somewhat ambiguous. In v. 30, "their rock" is clearly YHWH, as seen from the fact that YHWH is paralleled with "their rock" in the next stich, and the antecedent is YHWH's people, who are handed over to their enemies. Yet in v. 31 "their rock" appears to be referring to the god of the enemy nation contrasted with "our rock"- that is, Israel's God. Even this ambiguity buttresses the argument that the Song was performed, since a change of speaker most likely took place here and notified the congregation that the two occurrences of "their rock" in vv. 30-31 refer to two different antecedents- the first Israel, the second the enemy nation.

${ }^{22}$ Changes occur also from second person singular to second person plural and vice versa. Since such changes are not restricted to the Song of Moses itself (i.e., 32:3- "Give" [pl.]; 32:7"Ask" [sg.]) but are a phenomenon attested throughout the book of Deuteronomy, nothing will be made of their presence within the Song.

This article was published in JBL 123/3 (2004) 401-424, copyright @ 2004 by the Society of Biblical Literature. To purchase copies of this issue or to subscribe to JBL, please contact SBL Customer Service by phone at 877-725-3334 [toll-free in North America] or 802-864-6185, by fax at 802-864-7626, or visit the online SBL Store at www.sbl-site.org. 
the Song was not merely to be read but was to be performed. The changes in person may well mark off speeches of different people in the performance of the Song. It is also clear from the references to the people in the second person that a congregation is present and is being addressed.

Added to these shifts in grammatical person is the number of different speakers in the Song. Although it is unclear how many speakers there are in the first nineteen verses, it is possible that there are multiple speakers, as suggested by the shifts noted above. In v. 20, however, there is a clear change in speakerfrom the narrator to YHWH himself. YHWH's speech extends from v. 20 to v. 27. Although it is possible that vv. 28-30 continue YHwH's speech, they may be an explanation of why he feared the nation would misunderstand him. In v. 31, the speaker is clearly a representative of Israel. Once again, it is unclear where Israel stops speaking-after v. 31 or after v. 33? Verses 34-35 contain YHWH's second speech, after which the claim is made that he will vindicate his people. Then vv. 37-42 contain YHWH's final speech, which is followed by a summons of praise to the heavens and gods as a result of YHWH's actions. Once again, these changes in speaker are indicators that the Song was meant to be performed, with a number of people or groups speaking out the various sections.

Further, in common with liturgical songs, there are a number of commands and interrogatives that presuppose that there is a congregation present. In v. 3 the speaker summons his hearers to "Give greatness to our God!" It is quite likely that the following verse was the choral response to this command: "The Rock, his work is perfect for all his ways are just. A God of faithfulness and without iniquity, righteous and upright is he!" In v. 6 the people are confronted with two questions that emphasize the heinousness of rebellion: "Is this how you repay YHWH? ... Is he not your father?" In v. 7 the nation is commanded to "remember," "consider," and "ask your fathers/elders." The passage that follows these imperatives may have been performed by a group of elders, acting out the answering of v. 7 . In v. 30 another interrogative is directed possibly to the people but most likely to the enemy: "How did one pursue one thousand, and two cause a myriad to flee, unless their Rock sold them ... ?" Again, YHWH asks the enemy nation about his judgment: "Is it not stored up with me, sealed up in my storehouses?" (v. 34). Then, turning back to his people, YHWH asks: "Where are their gods, the rock in whom they took refuge?” In v. 39, YHWH calls his people to "see" that he alone is God. Finally, at the end of the Song, another command is given, only this time to the heavens and the gods: "Sing for joy, O heavens, with his people, and bow down to him all gods."23 Once again, my suggestion is

${ }^{23}$ The textual discussion surrounding this verse is somewhat complex. The MT provides a shorter reading than the variants preserved in the LXX and at Qumran but is also the "easier" read-

This article was published in JBL 123/3 (2004) 401-424, copyright ( 2004 by the Society of Biblical Literature. To purchase copies of this issue or to subscribe to JBL, please contact SBL Customer Service by phone at 877-725-3334 [toll-free in North America] or 802-864-6185, by fax at 802-864-7626, or visit the online SBL Store at www.sbl-site.org. 
that these imperatives and interrogatives, interspersed throughout the Song, are best understood in the context of a liturgical ceremony.

\section{Rîbôt and the Song of Moses}

To demonstrate that these features are most likely to be associated with liturgy, it will be illuminating to examine briefly the rîbôt that Wright notes (Ps 50; Isa 1:2-3; Jer 2:4-13; and Mic 6:2-8). While a number of these features do occur in other lawsuits that are not contained in liturgical texts, at a number of points significant differences do exist.

\section{Psalm 50}

Psalm 50 is a prophetic psalm containing a $r \hat{\imath} b .{ }^{24}$ The setting of the performance of this psalm is the temple on Zion (v. 2). Verses 1 and 4 contain the summons to the heavens and earth common to the rîb: "He calls to the heavens above and to the earth" with the explicit purpose that he might "judge (דין) his people." As in Huffmon's analysis of this form, the defendant is summoned (v. 5) and is addressed in the second person (vv. 7-15). The accusation, ending in v. 13, is formed in a question: "Do I eat the flesh of bulls, or the blood of goats do I drink?" The accusation is that, while the people have offered sacrifices, they have misunderstood the nature of these rites. The lawsuit ends not with a judgment, but with a warning: "Understand this, . . lest I tear apart and there is no one to deliver" (v. 22).

This psalm, like Deut 32, contains imperatives/interrogatives, multiple speakers, and grammatical shifts in person when referring to Israel. In v. 5 the people are commanded to "gather" and in v. 6 to "hear" YHWH's charge against them. Then, in vv. 14-15 the people are commanded to "offer" sacrifices of thanksgiving, "pay" vows, and "call" on YHWH in the time of trouble. Finally, in v. 22, the wicked are commanded to understand what YHWH has told them, that they might escape his judgment. Further, there are two speakers in this psalm. In the first four verses God is addressed in the third person and the stage is set

ing, since it makes no mention of gods. I believe the reading found in 4QDeut 9 is to be preferred based on both lectio difficilior (containing the reference to "gods" that is lacking in the MT) and on lectio brevior (being a shorter variant than the LXX). If so, the verse should read: "Rejoice, O heavens with his people; bow to him all gods. For the blood of his sons he will avenge and vengeance he will return upon his enemies, and to those who hate him he will repay, and he will atone for the land of his people."

${ }^{24}$ See Hans-Joachim Kraus, Psalms 1-59 (trans. Hilton C. Oswald; CC; Minneapolis: Fortress, 1993), 488-89; Craig C. Broyles, Psalms (NIBC 11; Peabody, MA: Hendrickson, 1999), $223-25$.

This article was published in JBL 123/3 (2004) 401-424, copyright @ 2004 by the Society of Biblical Literature. To purchase copies of this issue or to subscribe to JBL, please contact SBL Customer Service by phone at 877-725-3334 [toll-free in North America] or 802-864-6185, by fax at 802-864-7626, or visit the online SBL Store at www.sbl-site.org. 
for his speech. The rest of the psalm is YHWH's speech to his people and a warning to the wicked. Finally, Israel is referred to in the first person plural in v. 3"Our God comes," while in the remainder of the psalm is addressed in the second person.

One might suggest that these parallels between Deut 32 and Ps 50 are a result of the rîb pattern, but a better explanation can be found. First, the setting of the psalm is that of the temple in Zion (v. 2). ${ }^{25}$ Second, the imperatives in the psalm, particularly those in v. 14, demand that the psalm be performed at the temple: "Offer to God thanksgiving, and pay to the Most High your vows. . . ." Finally, the very content of God's lawsuit with his people is cultic. God's complaint against his people is that they have misunderstood the significance of sacrifices. Since Ps 50 is a liturgical work containing a rîb, it is difficult to determine whether the features it has in common with Deut 32 are due to a lawsuit form or a liturgical context.

Isaiah 1:2-3

Isaiah 1:2-3 contains another rîb against the people of YHWH. As is common in the pattern, heaven and earth are invoked to listen to YHWH's words (v. 2a). The accusation against the people is that while he has reared them, they have rebelled (vv. 2b-3). The rîb pattern ends here and a woe oracle follows. ${ }^{26}$ Although there is a change of speaker from the prophet to $\mathrm{YHWH}$, there are no imperatives addressed to any congregation, nor are there any grammatical shifts in person when referring to Israel. Thus, Isa 1:2-3 is a rîb that differs significantly from the Song of Moses, which has imperatives addressed to a congregation and multiple shifts in person when referring to Israel.

Jeremiah 2:4-13

Jeremiah 2 contains another rîb, mixed with a number of other forms. ${ }^{27} \mathrm{~A}$ number of components of the lawsuit form, albeit in unexpected order, are found in vv. 4-13. The command to the heavens/earth, found in v. 12, is not "to hear" but rather to "be appalled." The rîb begins by summoning the defendant

${ }^{25}$ Kraus suggests that the psalm was used in a covenant renewal festival (Psalms 1-59, 490-91). So too Peter C. Craigie, Psalms 1-50 (WBC 19; Waco: Word Books, 1983), 363. Such a possibility is perhaps buttressed by the thunderstorm theophany in vv. 1-3, which Exodus associates with Mount Sinai, where the original covenant was formed.

${ }^{26}$ See Hans Wildberger, Isaiah 1-12: A Commentary (trans. Thomas H. Trapp; Minneapolis: Fortress, 1991); Joseph Blenkinsopp, Isaiah 1-39: A New Translation with Introduction and Commentary (AB 19; New York: Doubleday, 2000), 182.

${ }^{27}$ The chapter is made up of a series of oracles woven together. For a discussion of the component parts, see Peter C. Craigie et al., Jeremiah 1-25 (WBC 26; Dallas: Word Books, 1991), $20-21$.

This article was published in JBL 123/3 (2004) 401-424, copyright ( 2004 by the Society of Biblical Literature. To purchase copies of this issue or to subscribe to JBL, please contact SBL Customer Service by phone at 877-725-3334 [toll-free in North America] or 802-864-6185, by fax at 802-864-7626, or visit the online SBL Store at www.sbl-site.org. 
to hear YHWH's accusation (v. 4). A question addressed to the defendant is then asked: "What wrong did your fathers find in me that they went far from me and went after worthlessness, and became worthless?" As in the Song of Moses, the people's sin is expressed in terms of idolatry (v. 11). No basis of accusation against YHWH can be found-he had saved them from Egypt and had brought them into a garden land. The people's response of disobedience was undeserved.

Although there is an imperative to the people in v. 4, it is in keeping with the rîb pattern-summoning the defendant to his trial. There are a number of imperatives in v. 10 to discover if another nation has abandoned their god(s) as God's people have abandoned him. Further, the interrogatives of vv. 7 and 11 belong to the rîb pattern of asking the defendant a rhetorical question as part of the indictment. As is normal in the lawsuit, the form begins with an invocation of the prophet/narrator that introduces YHWH's indictment speech. The rest of the passage is YHWH's speech. Finally, there is a shift from Israel being addressed in the second person singular to being referred to in the third person singular (vv. 11, 13). ${ }^{28}$

\section{Micah 6:1-8}

Another example of a lawsuit is found in Micah 6:1-8. ${ }^{29}$ In v. 2 the mountains are summoned to hear God's contention (ריב) with his people. YHWH's question to his people is: "What have I done to you, and in what have I wearied you?" Then, to demonstrate that the people have no basis for accusation against YHWH, he reminds them of his gracious provision for them in delivering them from Egypt and bringing them through the wilderness (vv. 4-5). The content of this lawsuit is in many ways similar to that of Ps 50—a misunderstanding with regard to the significance of the cult. In response to the breach of covenant that has occasioned the lawsuit of vv. 1-5, it is asked how one might enter into YHWH's presence. ${ }^{30}$ The question is then asked whether sacrifices will help him obtain his desire (vv. 6-7). The answer of v. 8 points in a different direction. The requirement was not sacrifice, instead: "What is good, and what does YHWH

${ }^{28}$ For a discussion of comparisons and contrasts between Jer 2 and Deut 32, see Jack Lundbom, Jeremiah 1-20: A New Translation with Introduction and Commentary (AB 21A; New York: Doubleday, 1999), 109-17; William L. Holladay, "Jeremiah and Moses: Further Observations," JBL 85 (1966): 17-27.

${ }^{29}$ While two different forms can be detected in this passage, that of a lawsuit (vv. 1-5) and an entrance liturgy (vv. 6-8), the two are combined to form a unified composition. So too Leslie C. Allen, The Books of Joel, Obadiah, Jonah, and Micah (NICOT; Grand Rapids: Eerdmans, 1976), 363; Hans Walter Wolff, Micah: A Commentary (trans. Gary Stansell; Minneapolis: Augsburg, 1990), 166-69.

${ }^{30}$ James Luther Mays thinks that Israel may be asking this question (Micah: A Commentary [OTL; Philadelphia: Westminster, 1976], 137-38).

This article was published in JBL 123/3 (2004) 401-424, copyright @ 2004 by the Society of Biblical Literature. To purchase copies of this issue or to subscribe to JBL, please contact SBL Customer Service by phone at 877-725-3334 [toll-free in North America] or 802-864-6185, by fax at 802-864-7626, or visit the online SBL Store at www.sbl-site.org. 
seek from you but to do justice, and to love kindness, and to walk humbly with your God?" The contention that God has with his people, then, is that the sacrificial system has been misunderstood and has eclipsed concerns for social justice. $^{31}$

Micah 6:1-8 also contains imperatives/interrogatives (vv. 1, 2, 3, 5, 6, 7, 8) and changes in speaker (vv. 1-5 [YHWH]; 6-8 [narrator]). That the rîb contains an imperative to hear and an interrogative to the defendant is part of the form and thus not surprising. Further, the imperatives and interrogatives of vv. 6-8 are in line with a liturgy of temple entry. The changes in speaker are explained by the fact that vv. $1-5$ belong to the form of a rîb while vv. $6-8$ are at the very least modeled after a psalm of temple entry. ${ }^{32}$ What is missing from Mic 6:1-8 is YHWH's sentence. Instead, the passage has a didactic purpose, instructing the people of the requirements that YHWH has for them. Gratefulness for YHWH's saving deeds is expressed not merely in sacrifices but in human relations as well.

V. Lawsuits and the Liturgical Aspects of the Song of Moses

Since all of these lawsuits contain imperatives, it will be helpful to place the evidence in a table below. Imperatives will be divided into three groups: (1) imperatives to elements of nature; (2) to Israel that are not related to worship; and (3) imperatives to Israel that are worship imperatives.

\begin{tabular}{|cc|}
\hline Imperative & Passages \\
\hline To Heaven/Earth/Mountain & Ps 50:1, 4 (implicit); Mic 6:2; Isa 1:2; \\
& Jer 2:13; Deut 32:1 \\
& Ps 50:4; Mic 6:5; Jer 2:4, 10; \\
To People: Gather/Hear/ & Deut 32:7, 39 \\
Remember/See & Ps 50:14; Deut 32:3b, 43 \\
To People: Worship/cultic & \\
\hline
\end{tabular}

\footnotetext{
${ }^{31}$ Such thinking is in line with other temple entries, such as Pss 15 and 24. In both of these psalms a principal requirement for temple entry is social, not sacrificial.

${ }^{32}$ Gunkel and Begrich suggest that Mic 6:6-8, along with Isa 33:14-16, are prophetic imitations of Torah liturgy (Psalms, 313-14). See the discussion on the cultic background to these verses in Francis I. Andersen and David Noel Freedman, Micah: A New Translation with Introduction and Commentary (AB 24E; New York: Doubleday, 2000), 510-11.
}

This article was published in JBL 123/3 (2004) 401-424, copyright @ 2004 by the Society of Biblical Literature. To purchase copies of this issue or to subscribe to JBL, please contact SBL Customer Service by phone at 877-725-3334 [toll-free in North America] or 802-864-6185, by fax at 802-864-7626, or visit the online SBL Store at www.sbl-site.org. 
From this table we see that there is a qualitative difference between some of the commands. The first two types, those to elements of nature and those to the people to "hear" and so on, belong with the rîb pattern as discussed by Wright. The third type is not indigenous to the lawsuit pattern and is thus lacking from all but Ps 50 and Deut 32. The reason that these "imperatives of worship" are found in these two passages is that both are liturgical texts. The interrogatives found in all but Isa 1:2-3, primarily belonging to the disputation form as well, are rhetorical questions meant to demonstrate YHWH's argument against his people. Shifts in speaker, while occurring in all rîb passages, are only a switch from the prophet/narrator to YHWH. The prophet's speech is meant to preface YHWH's message to his people; such a change of speaker is expected in prophetic oracles. On the other hand, as shown above, numerous changes of person occur within the Song of Moses that are not accounted for by the form of the $r \hat{\imath} b$ but can be explained if the Song is liturgical. Finally, grammatical shifts of person when referring to Israel likewise occur in other lawsuits-Ps 50, Mic 6:2-8, and Jer 2:4-13. Psalm 50 and Mic 6:2-8 change only once, from referring to Israel in the third person to addressing the nation in the second person. But this grammatical shift is due to the change in speaker that occurs at these points (Ps 50:3/4; Mic 6:1/2). Isaiah exhibits no such shift. Jeremiah, on the other hand, like Deut 32, has a grammatical shift within YHWH's speech. Up until Jer 2:9 the people are addressed in the second person, but at v. 11 there is a shift to the third person singular "my people." It is possible, though, that Jer $2: 4-13$ is actually composite, containing what were originally two separate oracles. ${ }^{33}$ Nevertheless, the numerous shifts in grammatical person in Deut 32:1-43 are sufficiently distinct to suggest that the text had a liturgical purpose. This, coupled with the imperatives of worship and multiple speakers, distinguishes the Song of Moses from other lawsuits and points to a different purpose.

\section{The Liturgical Aspects of the Song and Liturgies of the Psalter}

Since these three factors (shifts in person, changes of speaker, and imperatives/interrogatives) lead one to conclude that in the Song we have evidence of a liturgical work of Israel, it is best to compare the Song of Moses to liturgies of

\footnotetext{
${ }^{33}$ See Lundbom, who argues that wv. 5-9 are a discrete chiastic unit, introduced by v. 4 and demarcated by the phrases "thus said YHWH" in v. 5 and "oracle of YHWH" in v. 9 (Jeremiah, 256-57). If so, the grammatical shift that occurs between vv. 5-9 and vv. 10-13 in reference to Israel is explained.
}

This article was published in JBL 123/3 (2004) 401-424, copyright @ 2004 by the Society of Biblical Literature. To purchase copies of this issue or to subscribe to JBL, please contact SBL Customer Service by phone at 877-725-3334 [toll-free in North America] or 802-864-6185, by fax at 802-864-7626, or visit the online SBL Store at www.sbl-site.org. 
Scripture. These factors indicate not only that the Song was used as a liturgy in Israel's history but that it was written with that very intention. The grammatical features examined above can be fully explained only if the Song originated with the purpose of being used in such a setting. To demonstrate that these features in Deut 32 do indeed point to the liturgical origin and use of the Song, we can compare the Song to two psalms that are widely regarded as liturgical and possess these very attributes.

Psalm 24 is generally regarded as a psalm of temple entry. ${ }^{34}$ As worshipers entered the temple area to partake in the cultic activity, such a psalm ushered them into the sacred space. Although there are no shifts of person in the psalm, the other two features of Deut 32 do occur. At two points in the psalm (v. 8a/8b; v. 10a/10b) a question is asked: "Who is this king of glory?" Immediately following, the answer is given, presumably by another speaker: "YHWH, strong and mighty, YHWH, mighty in battle." This change in speaker indicates a performance of the psalm. Further, just as Deut 32 contains imperatives and interrogatives, Ps 24 includes a mix of imperatives and interrogatives that are explicable if the psalm is performed. "Who will ascend the hill of YHWH? And who will stand in his holy place?" This question hints at an audience. To the worshiper seeking entrance to the temple grounds, such a question is of immediate importance. The cultic space was not something to be entered trivially. The imperatives and interrogatives in vv. 7-10 - the imperatives to the gates and the interrogatives seeking answer to the question, Who is the king of glory?would likely have accompanied the entrance of the ark of the covenant into the city of Jerusalem. ${ }^{35}$

The second psalm is Ps 2, a royal psalm, likely used at the enthronement of a king or at the time the kings went out to war. ${ }^{36}$ In this psalm there are numerous shifts in person when YHWH is referred to. The first verses refer to him in the third person (he/YHWH). The sixth verse, which records YHWH's speech to the nations shifts into the first person singular. Verse 7a, however, reverts back to referring to YHWH in the third person. Again the psalm shifts back to the first person in v. 7c. Finally, in vv. 11-12, YHWH is referred to in the third person. Changes of speaker also occur in the psalm. Verses 1-2 contain a statement by the "narrator" about the kings, followed by their speech in vv. 4-5 and then by

${ }^{34}$ See Broyles, Psalms, 127-32; Gerstenberger, Psalms, 117-19; Mowinckel, Psalms I, 5-6; Klaus Koch, The Growth of the Biblical Tradition: The Form-Critical Method (trans. S. M. Cupitt; New York: Scribner, 1969), 30. See also Gunkel and Begrich, who view Ps 24 as a Torah liturgy (Psalms, 289-92).

35 Broyles, Psalms, 131.

${ }^{36}$ See ibid., 44-48; Mowinckel, Psalms I, 75. So too, with some reservation, Craigie, Psalms 1-50, 64-65. John H. Eaton believes that there are no changes in speaker and that the king performed the entire psalm alone (Kingship and the Psalms [SBT 32; London: SCM, 1976], 111). This conclusion does not do justice to the evidence in the psalm.

This article was published in JBL 123/3 (2004) 401-424, copyright ( 2004 by the Society of Biblical Literature. To purchase copies of this issue or to subscribe to JBL, please contact SBL Customer Service by phone at 877-725-3334 [toll-free in North America] or 802-864-6185, by fax at 802-864-7626, or visit the online SBL Store at www.sbl-site.org. 
the "narrator's" statement about YHWH's response. Verse 6 contains YHWH's speech, and vv. 7-9 are likely the speech of the king, retelling YHWH's words to him. The psalm ends with the "narrator" commanding the kings of the nations to respond appropriately to YHWH. Finally, Ps 2 contains a number of imperatives and interrogatives. The psalm begins with the question: "Why are the nations in tumult and the nations plotting in vain?" In v. 8, the king retells YHWH's command to him: "Ask of me ...." Verses 10-12 contain a number of imperatives addressed to the kings of the nations ("Be wise," "Be warned," "Serve," and "Kiss"). The following table shows that psalms generally regarded as liturgies contain shifts in grammatical person, multiple changes of speaker, and imperatives and interrogatives. This strengthens the argument that Deut 32 is a liturgy.

\begin{tabular}{|lll|}
\hline \multicolumn{1}{|c}{ Liturgical Feature } & \multicolumn{1}{c|}{ Psalm 24 } & \multicolumn{1}{c|}{ Psalm 2 } \\
\hline Person shift & - & Vv. 1-5 (3rd); 6 (1st); \\
& & $7 \mathrm{a}-\mathrm{b}(3 \mathrm{rd}) ; 7 \mathrm{c}-8(1 \mathrm{st}) ;$ \\
& & $11-12$ (3rd) \\
Change in speaker & Vv. 8a/8b, 10a/10b & Vv. 2/3, 4-5/6,7a/7b-9 \\
Imperatives/Interrogative & Vv. 2,3,7,8,9,10 & Vv. 1, 10,11,12 \\
\hline
\end{tabular}

VII. The Structure of the Song of Moses

As noted in regard to Wright's analysis, any attempt at a structural analysis of the Song should begin at the grammatical level and follow these clues in determining the shape of the work. The proposed structure of the Song is set forth below. Any attempt to reconstruct a liturgy centuries old is fraught with peril, but this can be mitigated by paying attention to the speaker and the grammatical person in which Israel is addressed. At a number of places it is uncertain where the speech of one participant in the liturgy ends and another begins. Also uncertain at times is the identity of the speaker as the Song is performed. Despite these uncertainties, the liturgical use of the Song remains a robust argument. On the following page is a hypothetical reconstruction of how the Song was performed.

Granting that the identity of the speaker in each section of the Song is not necessarily clear, this is an attempted reconstruction of how the liturgy might have been performed. The speaker who performs the speeches of YHWH would most naturally be a priest or a cultic prophet. Aubrey R. Johnson has argued

This article was published in JBL 123/3 (2004) 401-424, copyright @ 2004 by the Society of Biblical Literature. To purchase copies of this issue or to subscribe to JBL, please contact SBL Customer Service by phone at 877-725-3334 [toll-free in North America] or 802-864-6185, by fax at 802-864-7626, or visit the online SBL Store at www.sbl-site.org. 


\begin{tabular}{lll}
\hline Verses & \multicolumn{1}{c}{ Content } & Speaker \\
$1-3$ & Introduction & Officiator \\
4 & Hymnic praise & Choir \\
$5-6$ & Indictment summary & Officiator \\
7 & Hymnic imperative & Officiator \\
$8-14 \mathrm{c}$ & YHWH's acts recounted & Elders \\
$14 \mathrm{~d}$ & People addressed in second person & Officiator \\
$15 \mathrm{a}-\mathrm{b}$ & People indicted & Choir \\
$15 \mathrm{c}$ & Condemnation of people in second person & Officiator \\
$15 \mathrm{~d}-17 \mathrm{~b}$ & Israel's unfaithfulness recounted & Choir \\
$17 \mathrm{c}-18$ & Condemnation of people in second person & Officiator \\
$19-20 \mathrm{a}$ & YHWH sentences his people & Choir \\
$20 \mathrm{~b}-29^{37}$ & YHWH's speech: judgment and mitigation & Priest ${ }^{38}$ or \\
& & Cultic Prophet \\
$30^{39}$ & Question asked of the nations & Officiator \\
$31-33^{40}$ & Choral response & Choir \\
$34-35$ & YHwH's second speech & Priest or \\
& & Cultic Prophet \\
$36-37 \mathrm{a}$ & Proclamation of salvation & Choir \\
$37 \mathrm{~b}-38 \mathrm{~b}$ & YHwH's third speech & Priest or \\
& & Cultic Prophet \\
$38 \mathrm{c}-\mathrm{d}^{41}$ & Confrontation of Israel in second person & Officiator \\
$39-42$ & Conclusion of YHWH's third speech & Priest or \\
& & Cultic Prophet \\
43 & Second summons to praise & Officiator \\
\hline
\end{tabular}

${ }^{37}$ This speech may stop at v. 27. Then vv. 28-29 would belong with the speech of v. 30. With no first-person pronouns it is difficult to tell who is speaking. Perhaps since there is no clear demarcation of a new speaker it is safest to assume that wv. 28-29 continue YHWH's speech and that v. 30 is a new speaker, since YHWH is referred to in the third person.

${ }^{38}$ If the Song does have its origins after the inception of the monarchy, the "voice" of YHWH may well have been the king, particularly if there is truth to the claims of the Scandinavian Myth and Ritual school (John H. Eaton and others; see, e.g., Eaton, Kingship). That the king played such a central role in liturgical performances is largely speculative.

${ }^{39}$ This verse could just as easily be understood as part of the speech of the choir that follows in vv. 31-33.

${ }^{40}$ Once again it is unclear whether vv. 32-33 are the speech of the choir or form a new speech performed by the priest. As above, since there are no clear indicators, it will be assumed that the speech of the choir continues.

${ }^{41}$ This may be a continuation of YHWH's speech. The shift in person, from referring to Israel in the third person to addressing her in the second person, suggests that a change in speaker may take place here as well.

This article was published in JBL 123/3 (2004) 401-424, copyright @ 2004 by the Society of Biblical Literature. To purchase copies of this issue or to subscribe to JBL, please contact SBL Customer Service by phone at 877-725-3334 [toll-free in North America] or 802-864-6185, by fax at 802-864-7626, or visit the online SBL Store at www.sbl-site.org. 
that the entire Song is a psalm that reflects the activity of cultic prophets who were responsible for delivering oracles of YHWH to the nation in time of national crisis. ${ }^{42}$ The director of the liturgy, who cries out the imperatives, questions, and charges directed to the congregation would be a cultic official, possibly levitical. ${ }^{43}$ The responses, whether to the officiator's questions and commands or the speeches of YHWH, would most naturally fall to the choir. One of these choral responses (vv. 8-15a), in keeping with the director's imperative that Israel ask its father and elders to relate the history of YHWH's dealings with the people, might have been performed by the elders of the congregation, reminding younger generations of YHWH's former faithfulness to them.

\section{Liturgical Setting of Performance of the Song}

One of the main axioms of form criticism, as stated by Sigmund Mowinckel, is that "the different types of psalms have come into existence in connexion with different cultic situations and acts to which they originally belonged." 44 Thus, what remains to be examined with regard to the liturgical use of the Song is where and when such a liturgy would have been performed. What cultic setting gave rise to the composition of the Song of Moses? Of the classical theories with regard to use of the psalms, Artur Weiser's proposal that the autumn festival was a covenant-renewal festival is the most promising habitat for the Song of Moses. ${ }^{45}$ Although his theory offers little evidence that such a festival existed, it would fit well with the arguments of many scholars that Deuteronomy is a covenant treaty document. ${ }^{46}$ Just as vassal treaties were periodically read to

\footnotetext{
42 Aubrey R. Johnson, The Cultic Prophet and Israel's Psalmody (Cardiff: University of Wales Press, 1979), 150-65. He argues that one of the features of this prophetic style is that the cultic prophet acts as the "mouthpiece of Yahweh" (pp. 6-7). He believes that the Song of Moses was performed by the cultic prophet, but this fails to account for the liturgical aspects of the Song, which seem to point to various "actors" in its performance. See also Steven J. L. Croft, who discusses the role of the cultic prophet in the preexilic period (The Identity of the Individual in the Psalms [JSOTSup 44; Sheffield: Sheffield Academic Press, 1987], 151-59).

${ }^{43}$ See Mark S. Smith, who argues that the Levites had liturgical and scribal functions in the postexilic period and were likely responsible for the compilation of the Psalter ("The Levitical Compilation of the Psalter," ZAW 103 [1991]: 258-63). This argument is bolstered by the fact that a number of psalms $(42,44-49,84,85,87,88)$ are associated with the sons of Korah, who were levitical. Such liturgical roles may have preceded this period as well.

${ }^{44}$ Mowinckel, Psalms I, 13.

${ }^{45}$ For Weiser's theory of the covenant-renewal festival, see the introduction to The Psalms: A Commentary (trans. Herbert Hartwell; OTL; London: SCM, 1962), in particular, pp. 35-52.

${ }^{46}$ See George E. Mendenhall, "Covenant Forms in Israelite Tradition," BA 17 (1954): 50-76; and Dennis J. McCarthy, Treaty and Covenant: A Study in Form in the Ancient Oriental Documents in the Old Testament (Rome: Pontifical Biblical Institute, 1963). For studies that exam-
}

This article was published in JBL 123/3 (2004) 401-424, copyright @ 2004 by the Society of Biblical Literature. To purchase copies of this issue or to subscribe to JBL, please contact SBL Customer Service by phone at 877-725-3334 [toll-free in North America] or 802-864-6185, by fax at 802-864-7626, or visit the online SBL Store at www.sbl-site.org. 
renew the stipulations and the curses/blessings of the treaty, so too the covenant in early Israel was likely renewed from time to time (Deut 31). The Song of Moses may well have formed an important part of such a ceremony, which may have taken place in Shechem, as Deut 27 suggests, with one part of the nation standing on Mount Gerizim and the other on Mount Ebal. ${ }^{47}$

That the temple was not the original setting of this performance is possible, since the sacrificial system is not mentioned and none of the cultic apparatus alluded to. The sin of the people is cast in terms of idolatry, but no mention is made of the temple, the ark, Zion, and so on. Three possibilities arise: (1) The Song originated while the temple existed, but use of it was not tied to the temple cult. (2) The Song predates the establishment of the temple cult. (3) The Song was written after the destruction of the temple but before its being rebuilt. The third option seems unlikely, since no hint is made of either the exile or the destruction of the temple. Based on the silence about the temple, neither of the first two options is to be clearly favored. ${ }^{48}$ But, in light of the lack of any reference to the monarchy and the conditions of life during that period, it is possible that the Song predates both the temple and the establishment of the monarchy. ${ }^{49}$

\section{Readdressing the Question of Form}

We are now in a better position to return to the discussion of the form of the Song. If this liturgical understanding of Deut 32 is to be accepted, then the question of genre will be informed by other liturgies, primarily those entrenched in Israelite culture. Cultic poetry has generally been divided into the following classifications: lament (communal and individual), complaint (communal and individual), thanksgiving (communal and individual), hymns,

ine Deuteronomy specifically, see Meredith G. Kline, Treaty of the Great King: The Covenant Structure of Deuteronomy: Studies and Commentary (Grand Rapids: Eerdmans, 1963); Moshe Weinfeld, Deuteronomy and the Deuteronomist (Oxford: Clarendon, 1972), 59-157.

${ }^{47}$ The antiquity of some of the traditions contained in Deut 27-34 is seen particularly clearly in ch. 27. As in Exod 20:25, Deut 27:5-6 says that an altar must be of uncut stone but does not need to be at a central place of worship; Deut 12 reflects later concerns for the centralization of worship. Further, evidence for the antiquity of this tradition is that Levi is included in the tribal list, and the division of the house of Joseph into Manasseh and Ephraim had not yet happened.

${ }^{48}$ The omission of any reference to cultic apparatus or the temple is uncommon in hymns; see Gunkel and Begrich, Introduction, 41-43; Mowinckel, Psalms I, 89-90.

${ }^{49}$ So too, Cassuto, Biblical and Oriental Studies, 1:41. Lack of references to the temple and monarchy is an inconclusive indicator of where the Song was performed. Numerous psalms likely performed at the temple make no mention of the temple or the monarchy, e.g., Pss 33; 103; 104; 105 ; 113 ; etc.

This article was published in JBL 123/3 (2004) 401-424, copyright @ 2004 by the Society of Biblical Literature. To purchase copies of this issue or to subscribe to JBL, please contact SBL Customer Service by phone at 877-725-3334 [toll-free in North America] or 802-864-6185, by fax at 802-864-7626, or visit the online SBL Store at www.sbl-site.org. 
royal psalms, and wisdom psalms. ${ }^{50}$ Considered in terms of the established liturgies contained in the Psalter, the Song contains all the elements of the form of a hymn. Using Ps 33 as an example, we can delineate the four main components of a hymn as follows: ${ }^{51}$

1. Command to Praise/Call to Worship: Ps 33:1-3 ("Rejoice in YHWH ...")

2. Introductory Summary: 33:4-5 ("For the word of YHWH is upright ...")

3. Body: 33:6-19 (A description of God's goodness and greatness)

4. Renewed Call to Praise or Blessing/Wish: 33:20-22 ("Let thy steadfast love ...")

Deuteronomy 32 evinces these same elements. (1) The call to worship is in v. 3: "Give greatness to our God!" (2) The introductory summary is in the following verse: "The Rock, his work is perfect for all his ways are just. A God of faithfulness and without iniquity, righteous and upright is he!" (3) Praise of YHWH for his works, deeds, and qualities, the predominant section of a hymn as well as that of the Song of Moses, is found in 32:8-14, 30-42. The emphasis is primarily on the goodness of God to Israel, although God's greatness is also mentioned (vv. 8, 12, 39). But it is the goodness of God in spite of the judgment that is meted out to the people that is emphasized. In a sense, the designation of Deut 32:1-43 as a "hymn" approaches Gerhard von Rad's description of a Gerichtsdoxologie ("judgment doxology"): "The essence of this and every act of praise is that in all circumstances it declares God to be in the right." ${ }^{2}$ Proclaiming YHWH's righteousness and faithfulness (see v. 4) includes praise of YHWH's just punishment of his people. That the praise in Deut 32 is primarily in narrative form is in keeping with hymns in the Psalter such as Pss 78, 105, 106. ${ }^{53}$ Finally, (4) the concluding summons to praise in v. 43 is a command not only to Israel but to the heavens and the gods.

To define these aspects in the song more narrowly, three options present themselves based on the work of Frank Crüsemann, who divides this category of psalms into three groups: "imperative hymns," "hymnic participles," and "hymns of the individual." 54 The element of the imperatival hymn is the exhortation to praise followed by the reason to praise (often introduced by כי; see Pss $96 ; 98 ; 100 ; 117,136)$. The two imperatival sections in the Song (vv. 3, 43) sug-

${ }^{50}$ See, e.g., Gerstenberger, Psalms, 9-21; Broyles, Psalms, 9-22.

${ }^{51}$ Taken from Broyles, Psalms, 13-15. For similar descriptions of the form of a hymn, see also Gerstenberger, Psalms, 16-19; Mowinckel, Psalms I, 81-105.

52 Gerhard von Rad, Old Testament Theology, volume 1, The Theology of Israel's Historical Traditions (trans. D. M. G. Stalker; London: SCM Press, 1975), 359.

${ }^{53}$ See Gerstenberger, Psalms, 18.

${ }^{54}$ See Frank Crüsemann, Studien zur Formgeschichte von Hymnus und Danklied in Israel (WMANT 32; Neukirchen-Vluyn: Neukirchener Verlag, 1969), 19-154, 285-306, referred to by Kraus, Psalms 1-59, 43.

This article was published in JBL 123/3 (2004) 401-424, copyright @ 2004 by the Society of Biblical Literature. To purchase copies of this issue or to subscribe to JBL, please contact SBL Customer Service by phone at 877-725-3334 [toll-free in North America] or 802-864-6185, by fax at 802-864-7626, or visit the online SBL Store at www.sbl-site.org. 
gest that the Song may fit into Crüsemann's category of an "imperative hymn," as does the declaration of praise (here not introduced by 'כ) in v. 4. According to Crüsemann, the Sitz im Leben of the imperative hymn "[i]s the regular cultus, its original content the experience of Yahweh's historical treatment of Israel." "55 YHWH's historical treatment of his people is indeed exhibited clearly in the Song of Moses. The argument here is not necessarily that every verse in the Song belongs to the category of a hymn, ${ }^{56}$ but that every component of the form of the hymn is found in the Song and that understanding the Song as hymnic will aid in the interpretation of the purpose of it.

\section{A Covenant Rîb Embedded in a Hymn}

Combining the insights of Wright's study with the arguments offered here, we conclude that the Song of Moses is a hymn that contains a covenant rîb. This conclusion is not altogether different from Wright's own argument. The difference is one primarily of emphasis. Wright, and those who base their work on his essay, stress the idea of the rîb. Wright's statement that this lawsuit is merely an "instructional device" rightly points in another direction-to the subversion of this form to the purposes of the hymnic form. ${ }^{57}$ The rib in the context of the Song functions to underscore the hymnic introductory summary found in v. 4: "The Rock, his work is perfect, for all his ways are just. A God of faithfulness and without iniquity. Righteous and upright is he." The choir is to give the "Amen!" to this statement, associating themselves as representatives of the nation with the sinful generation indicted in the covenant lawsuit while at the same time confirming YHWH’s character.

\section{Implications for the Study of the Song}

The argument here is that the Song of Moses was not only used liturgically but was crafted for that very purpose. If this is correct, a number of significant propositions can be offered with regard to the critical issues of Deut 32.

${ }^{55}$ Crüsemann, Studien, 308, cited by Kraus, Psalms 1-59, 44.

${ }^{56}$ One could argue that nontraditional elements in the Song are an expansion of the hymnic form. Thus, the condemnation of the people (32:5-6) is meant to contrast with YHwH's faithfulness, and the narrative in vv. 8-42 could be understood to reflect this faithfulness of YHWH throughout Israel's history. In the wilderness, YнwH provided graciously for his people. The disobedience of the people (vv. 15-18) will lead YHwH to respond with just retribution (vv. 19-25). Yet he will not allow his name to be maligned and so will both judge the nation that harmed his people and restore his people (vv. 26-42).

${ }^{57}$ Wright, "Lawsuit," 54.

This article was published in JBL 123/3 (2004) 401-424, copyright ( 2004 by the Society of Biblical Literature. To purchase copies of this issue or to subscribe to JBL, please contact SBL Customer Service by phone at 877-725-3334 [toll-free in North America] or 802-864-6185, by fax at 802-864-7626, or visit the online SBL Store at www.sbl-site.org. 
First, a liturgical setting would have important implications for the dating of the Song. A survey of the critical studies on the date of the Song shows dates ranging from the eleventh century to the sixth century B.C.E. ${ }^{58}$ Proposed dates are based on vocabulary, poetic style, and theological parallels with the prophets. The disparity between scholarly opinions, particularly those based on vocabulary and poetic style, may have some basis in the data of the text, but this can be explained. If a liturgical background is accepted, then it can be assumed that the Song was passed down orally through cultic officials. As linguistic usage evolved over time, some changes in vocabulary and style probably crept into the liturgy. ${ }^{59}$ Thus, in the Song we may have evidence of language that represents various periods. This same point is made by Weiser in regard to the cultic hymns of the Psalter: " $[\mathrm{M}]$ any psalms were destined to repeated use as cultic hymns; they were therefore subject to the modifications of language and style which would take place in the course of history." 60 If such is the case, then any liturgical work might evince data that point both to an early and a late dating. ${ }^{61}$ In line with the dating of many psalms, the Song of Moses is probably preexilic in origin. ${ }^{62}$ This would account for linguistic evidence that points to an early date, and modifications that would slowly have made their way into the hymn as a liturgical work would explain vocabulary and stylistic evidence for a late date. This is in keeping with the work of Otto Eissfeldt, D. A. Robertson, and Paul Sanders, who argue for an early dating.

Second, an understanding that the Song originated in a liturgical context

58 This is not the place for a discussion of these arguments. The reader is referred to the following works for this analysis. For proposals of an early date, see Otto Eissfeldt, Das Lied Mose Deutronomium 32:1-43 und Das Lehrgedicht Asaphe Psalm 78: samt einer Analyse der Umgebung des Mose-Liedes (Berlin: Akademie-Verlag, 1958); D. A. Robertson, Linguistic Evidence in Dating Early Hebrew Poetry (SBLDS 3; Missoula, MT: Scholars Press, 1972), 153-56; Paul Sanders, The Provenance of Deuteronomy 32 (Leiden: Brill, 1996). A late date is proposed by James R. Boston, "The Song of Moses: Deuteronomy 32:1-43" (Th.D. diss., Union Theological Seminary in the City of New York, 1966); Mayes, Deuteronomy, 381-82; Gerhard von Rad, Deuteronomy: A Commentary (trans. Dorothea Barton; OTL; Philadelphia: Westminster, 1966), 200. Solomon A. Nigosian takes a mediating position, arguing that the mixture of early and late features points to a period of transition in Hebrew poetry and that Deut 32 should be dated between the tenth and eighth centuries B.C.E.

${ }^{59}$ One thinks of the modern example of attempting to "update" the King James Bible with the New King James Bible, primarily by replacing archaic language. While such updating took place, it in no way completely removed the evidence of an earlier style.

${ }^{60}$ Weiser, Psalms, 25.

${ }^{61}$ Moshe Weinfeld makes a similar point in regard to the structure of the book of Deuteronomy (Deuteronomy 1-11: An Introduction with Translation and Commentary [AB 5; New York: Doubleday, 1991], 13).

${ }^{62}$ See Gunkel and Begrich, who argue that the genre of the hymn is preexilic, citing the Song of Deborah, Ps 89, 1 Sam 2:1-10, etc., as examples of hymns that are clearly preexilic (Introduction, 319-20).

This article was published in JBL 123/3 (2004) 401-424, copyright @ 2004 by the Society of Biblical Literature. To purchase copies of this issue or to subscribe to JBL, please contact SBL Customer Service by phone at 877-725-3334 [toll-free in North America] or 802-864-6185, by fax at 802-864-7626, or visit the online SBL Store at www.sbl-site.org. 
illuminates the relationship of Deut 32 to prophetic literature. It has been argued by many that Deut 32 is dependent on the prophetic literature for its theology (and therefore is of late origin). For example, Carl H. Cornill has described the Song as a "compendium of prophetic theology."63 Yet, as recent scholars have argued, the primary direction of dependence between the two groups of literature is the prophets depending on the psalms, not vice versa. ${ }^{64}$ The spirituality of the prophets is informed greatly by the early liturgies of the psalms. So too are the prophets-Jeremiah and Hosea in particular-informed by the Song of Moses. ${ }^{65}$ This explanation provides a better alternative to the predominant theory that the Song is to be dated to the postexilic period based on theological similarities to the prophets.

Third, any attempt to determine the historical context that occasioned the Song is wrongheaded from the start. The Song, composed for a liturgical purpose, was not written to describe the response of a certain group of the people of God to a particular catastrophe that had come upon them at a specific time. Attempts to uncover the time of writing based on historical "clues" in the text or the "no-people" of 32:21 are doomed to failure no matter what evidence is marshaled in favor of this or that theory. It is not only the modern reader who finds the language of the Song vague and the identity of the "no-people" enigmatic. The language is purposefully vague and the enemy intentionally faceless. The author's goal was not to describe a particular historical situation but to compose a liturgical work that would not quickly become obsolete. The very nature of a liturgical work is that it lends itself to being used for recurring occasions. Thus, the only clear referents in the text are YHWH, Israel, and the election of Israel in the wilderness and the entrance into the land. The description of the covenant infidelity of the people (32:15-18), ${ }^{66}$ the resulting judgment of YHWH on his people through a foolish nation (32:19-33), and YHWH's judgment against his enemies and in favor of Israel (32:34-43) lack clear historical referents. Thus, Israel can use this history of itself in different time periods. The elements of the Song are not descriptions of historical events but warnings to the

${ }^{63}$ Cited in S. R. Driver, A Critical and Exegetical Commentary on Deuteronomy (ICC; Edinburgh: T \& T Clark, 1901), 346; see also Mayes, Deuteronomy, 381.

${ }^{64}$ See Mowinckel, Psalms I, 14; Claus Westermann, Isaiah 40-66: A Commentary (OTL; Philadelphia: Westminster, 1969), 23-27.

${ }^{65}$ See Holladay, "Jeremiah and Moses," 17-27, for an impressive list of parallels between the Song and Jeremiah; see also Cassuto, who states: "We shall be able to understand this entire complex of formal analogies with verses from the prophetic books much better, if we assume the song to be a very ancient text that was held in high esteem and was widely known, and that the prophets who came afterwards frequently recalled it. Since this is to be observed already in the case of Hosea, it serves to confirm the poem's great antiquity" (Biblical and Oriental Studies, 1:44).

${ }^{66}$ For example, it is not said which god(s) the nation chased after.

This article was published in JBL 123/3 (2004) 401-424, copyright ( 2004 by the Society of Biblical Literature. To purchase copies of this issue or to subscribe to JBL, please contact SBL Customer Service by phone at 877-725-3334 [toll-free in North America] or 802-864-6185, by fax at 802-864-7626, or visit the online SBL Store at www.sbl-site.org. 
congregation who performs the Song of what will happen to them if they forget YHWH.

Fourth, and most important for dealing with the intention of the Song, is the nature of a liturgy. A liturgy is prescriptive; it is a form of Torah. As Craig C. Broyles states:

Psalms are not descriptive poems; they are prescriptive liturgies. In other words, they are not private reflections of poets on a recent, private experience; they are composed as models to guide the expressions of Yahweh's worshipers in prayer and praise. Psalms are more concerned with leading the worshipers' experience than with following the composer's. ${ }^{67}$

The Song of Moses, as a liturgy, functions similarly. It does not describe someone's reaction to a historical catastrophe that has been visited upon the people of YHWH. Instead, the Song was meant to prescribe the people's reaction, both to guard them from acting like the sinful generation of the Song and to lead them in responding to any evil that was brought upon it. Just as the psalms do not describe David's (or anyone else's) response to personal situations but are meant to guide the community's thinking, worship, and response to YHWH, so too the Song of Moses. Liturgy, by its very nature, is instructive, and the Song of Moses is a command to the people of God throughout their history. Suffering will come upon them because of their covenant infidelity, and their response should be to "give greatness to our God." They are not to accuse him of wrongdoing but to acknowledge that his work is blameless, and his ways are just. YHWH is faithful and without iniquity, righteous and upright. The congregation is called on to remember not only the past acts of YHWH on behalf of the people but also their rebellious response. The congregation is to identify itself with the sinful generation described in the Song in the same way that they are to identify themselves with the generation who was enslaved in Egypt and delivered by YHWH (Deut 26:5-9). Yet in the midst of this, there is hope. YHWH will judge his enemies; he will vindicate the blood of his servants. Thus, in v. 43 there is another command to sing joyously. Those who want to maintain covenant fidelity with God will follow the imperatives of the Song, praising and waiting in hope for YHWH to act on their behalf. The basis for this hope and the theme that runs throughout the Song is stated in v. 4: "The Rock, his work is perfect, for all his ways are just. A God of faithfulness and without iniquity. Righteous and upright is he!"

${ }^{67}$ Broyles, Psalms, 3.

This article was published in JBL 123/3 (2004) 401-424, copyright @ 2004 by the Society of Biblical Literature. To purchase copies of this issue or to subscribe to JBL, please contact SBL Customer Service by phone at 877-725-3334 [toll-free in North America] or 802-864-6185, by fax at 802-864-7626, or visit the online SBL Store at www.sbl-site.org. 